\title{
Odontogenic Fibroma
}

National Cancer Institute

\section{Source}

National Cancer Institute. Odontogenic Fibroma. NCI Thesaurus. Code C4314.

A rare, benign, intraosseous neoplasm arising from tooth-forming tissues in the

mandible and maxilla. It is characterized by the presence of odontogenic epithelium which

is embedded in a fibrous stroma. Local enucleation of the tumor is curative. 